Now designated as wilderness-type areas are 83 separate tracts, about 8 percent of the 186 million acres of the national forest system. They are located on parts of 73 national forests in 14 states. Their combined area is 14.5 million acres.

During the past decade a number of citizens and organizations concerned with natural resources have advocated the creation of a wilderness preservation system by act of Congress. This proposed legislation would provide for three specific actions, among others. It would (1) include presently established wilderness areas in a wilderness preservation system; (2) specify the manner in which new wilderness areas or modifications of existing areas should be accomplished; and (3) specify the uses to be permitted within such areas.

Stated briefly, proponents of the legislation want the Congress to adopt a national policy on wilderness areas, and to specify procedures for their establishment, modification, and permitted uses. Under the proposed legislation, certain determinations with respect to presently established wilderness areas, such as the final modification of boundaries and the elimination of portions, would be removed from the discretion and authority of those responsible for their administration. Instead, consideration by Congress would be required.

Opponents of the legislation object to the statutory fixing of boundaries and the impossibility of withdrawals, except following Congressional review. Increasing demand by an expanding population for forest products and services should be correlated, they say, with such demand and with the acreage of forest available in each region. Many view the proposed wilderness preservation system as a "locking up" of vast areas for limited use, inconsistent with multiple-use management for the development of all renewable natural resources.

\title{
An Explanation of National Parks Policy on THE EXPloitation OF Forest REsOuRCES ${ }^{2}$
}

To most of us a park is simply a place where we enjoy nature and the outdoors and we are concerned only with the benefits we can derive from it. From this standpoint it matters little whether the park is a national, provincial or municipal park, or some other type of area. It is this essentially practical approach which often leads to uncertainty as to what constitutes a national park, and confusion as to standards of national calibre and quality, as compared with the requirements for local parks and other outdoor recreation facilities. In addition, large areas of undeveloped land are readily visible to casual visitors to our national parks because roads and trails have been developed in the parks for just that purpose-to bring large areas of land in its natural condition within easy reach of the people of Canada. To the forester this fact, combined with the impressive figure of 29,000 square miles comprising the parks, is apt to obscure the more realistic view that unexploited forest lands in the national parks represent only a fraction of one per cent of the accessible commercial forest lands in Canada.

\footnotetext{
1 This comprehensive explanation of the policy of Canada's National Parks has been given to the C.I.F. by the Hon. Mr. Walter Dinsdale, Minister of Northern Affairs and National Resources, Ottawa, Ont. It supplements his letter of Nov. 7, 1961, to J. J. E. Dosne acknopledging the C.I.F. resolution on National Parks policy passed at the 1961 Annual Meeting.
} 
Most land in Canada is blessed with great resources both hidden and apparent-land that can be used for farming-for lumbering-for miningfor hydro-electric developments. In setting aside and establishing an outstanding area as a national park the nation makes a decision on land use; it decides that the best and highest use of the area lies in preserving its natural features for the nation as a whole.

In many types of forest lands and in some categories of park lands a high emphasis on recreational use can be made concurrent with economic exploitation. This is not usually the case in national parks. The basic purpose of our national parks is to preserve for all time areas of national significance for their geographical, biological or geological features, as a natural heritage for the benefit, education and enjoyment of the people of Canada, present and future. Maintaining these areas unimpaired or preserving them is a very real part of our obligation. Establishing a national park means giving up for all time to come the possible economic advantages of exploiting the material resources of the area concerned and receiving in exchange the intangible benefits that belong in the realm of the spirit.

Theoretically the ideal national park would seem to be a virgin wilderness untouched by the hand of man. However, like any other resource, national parks have value only when they are made useful to man. Any development involves some impairment of the natural scene; but some development is essential to allow visitors access to park features so they can enjoy and benefit from them. This impairment is accepted on the basis that the increased use and enjoyment of the park made possible by such developments, outweigh the reduction in park values caused by the impairment.

The variation in nature and extent of national parks also suggests that certain parks can be subjected to secondary uses without detracting from their real purpose, while others cannot. Facilities for many types of outdoor recreations including golf, tennis, swimming, skiing and similar participant sports can be developed in most parks without significant impairment of basic park values.

The type and extent of permissible secondary uses of park lands must be assessed and planned for each park separately. Due consideration of economy in the administration of public funds and of the public convenience in the use made of park lands makes the management of any national park a compromise between what is desirable for a theoretically perfect park and what is practical in any particular situation from a financial and administrative standpoint.

In the case of forest resources no single detailed policy is applicable to all the national parks. The type of management depends on the most desirable use of each area. Obviously, where the wilderness character of an area is the main park value being protected any forest lands in the area should be as completely natural as possible. An area around a townsite or large campground should be managed to maintain a forest that will withstand the necessary visitor use without altering the natural scene appreciably. In Wood Buffalo National Park the basic park values being preserved are the herds of bison and a large natural bison range. The existence of extensive stands of commercially valuable timber in this park is entirely incidental to the nation- 
al parks value of the area and commercial exploitation of this timber is permitted. This one park, incidentally, contains over 17,000 square miles of the total of 29,278 square miles in the national parks system. In the remaining 17 national parks, with a total area of close to 12,000 square miles, the forest lands form an important part of the natural scene. Forest management policies in these parks vary from regular annual cuttings under a perpetual yield plan, as in Riding Mountain National Park where approximately 170 million F.B.M. of timber has been cut from the park since 1938, to an absolute "hands-off" policy in wilderness areas of other parks.

As previously noted, no single detailed policy is applicable to all national parks forests because of the wide variations in conditions which exist. However, two very clear general principles do exist. These are:

1. When a national park is established the possible economic advantages of exploiting the material resources are given up. Economic factors may govern whether or not some action beneficial to park values can be undertaken, but only forest operations which are primarily concerned with the management of the forests for the protection and management of national park values should be permitted.

2. The basic national park values are supplied by the natural scene, undamaged and unimpaired. Some modification and impairment of the natural scene is necessary to allow use of park resources by people. However, changes in the character of the park scene or modifications or impairments of the natural environment should be kept to the minimum necessary to allow intelligent and appropriate use of the park resource.

Both of these principles preclude forest operations whose sole or main object is the cutting and removal of timber products for their commercial value alone.

As our population increases and as the natural resources outside the parks continue to be exploited for commercial use, the intrinsic value of parks increases immeasurably. The grandeur of the park landscape, the scientific interest of the forests, wildlife and geological forms, and the natural relationships of plant and animal life can be maintained only if the lands and waters comprising the parks are kept essentially in their natural state.

Walter Dinsdale

\section{Current Publications MANAGEMENT}

Bernstein, D. A. 1961. An Evaluation of lithographed forest stereograms. Res. Note 212, P.N.W.F.R.E.S. Portland, Ore. 4 pp.

Blum, B. M. 1961. Age-size relationships in all-aged hardwoods. For. Res. Note 125 N.E.F.E.S. Upper Darby Pa. 3 pp.

Buckingham, F. M. 1961. Wood measurement-symposium. CPPA Woodl. Sec. Index 2053 (B-6). 8 pp.

Meyer, M. P. 1961. Aerial stand volume tables for northern Minnesota. Minn. For. Note 105. $2 \mathrm{pp}$

1961. A composite aerial stand volume table for northern Minnesota. Minn. For. Note 106. 2 pp. 